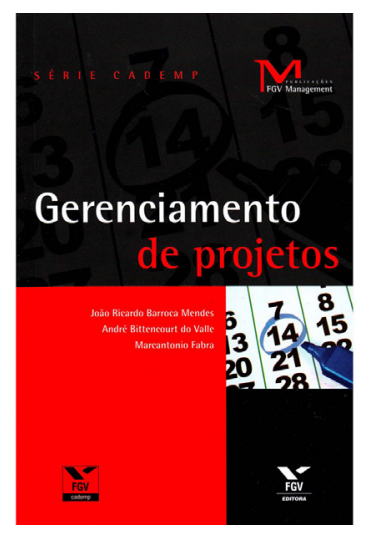

\section{Para desenvolver bons projetos também em Educação e Saúde}

Docente, há vários anos, da Disciplina de Seminários de Projetos (embora sob designações variadas) para diferentes cursos de graduação e, sobretudo, de pós-graduação, constatei, com muita frequência, o surgimento de proposituras intelectualmente atraentes e criativas tanto em Educação quanto em Saúde (talvez mais no âmbito da primeira que no da segunda), mas que não prosperam por falta de clareza e método de exposição. De resto, esta tem sido, também, a experiência de numerosos colegas da área, ao menos daqueles com que tenho abordado a questão. Portanto, ao deparar-me com texto a respeito que me pareceu precioso, julguei-me no compromisso de vir a um periódico de significativa circulação entre acadêmicos do país para apresentá-lo. Ainda que sua fria objetividade possa impactar, no primeiro momento, nosso olhar problematizador, trata-se de disponibilizar, aos colegas de ofício, ferramenta valiosa a que não tive oportunidade de recorrer quando teria sido tão útil.

Com efeito, a relação da vida acadêmica com a formulação de projetos parece tão inextrincavelmente
Mendes JRB, Valle AB, Fabra M. Gerenciamento de Projetos. Rio de Janeiro: Editora FGV, 2014.

Aguinaldo Gonçalves(a)

forte que sugere metáfora relativa à dependência do desenvolvimento biopsíquico para com a amamentação no seio materno. E isto não apenas pela via do ensino, mas, destacadamente, da pesquisa e extensão. Nessa direção, não parece exagero admitir que viver protagonicamente a cena universitária é estar mergulhado em projetos, no contraponto com o fato de que poucos de nós tivemos sequer algum tipo de formação na matéria. $\mathrm{Na}$ verdade, nossa hierarquia intelectual de interesses e envolvimentos parece priorizar tanto a área substantiva de nossa atuação, com suas intersecções e demais seduções, que pode, lamentavelmente, subalternizar a que consideremos apenas formalismos, para cuja vala comum deslocamos, intencionalmente ou não, o cuidado e a dedicação à composição e concretização de projetos enquanto tal. No entanto, viver é construir projetos: é sabido que a ausência destes é que transforma depressivos em suicidas.

Ora, esta obra atende aos requisitos de publicação necessária à formação e atuação das pessoas que lidam profissionalmente com a realidade dos projetos ou, até, daqueles que optam por operar suas atividades de forma preferivelmente organizada

\footnotetext{
(a) Disciplina Situações de Saúde, Faculdade de Medicina, Pontifícia Universidade Católica de Campinas. Av. John Boyd Dunlop, s/n, Jardim Ipaussurama. Campinas, SP, Brasil. 13060-904. aguinaldogon@ uol.com.br
} 
à circunstancial ou errática. Fruto do trabalho de especialistas ligados tanto ao mundo das ideias assim como ao das aplicações, este livro reúne características relevantes raramente vistas coexistindo simultaneamente: clareza de exposição, fundamentação teórica lastreada em fontes de plena legitimidade e envolvimento com o real dos fatos.

Estruturado em seis capítulos autônomos e complementares, dedica-se, logo de pronto, a 'aspectos gerais' e introdutórios da matéria, onde destacam-se gestões e documentos basilares a serem produzidos antes do deslanche, estes como, nomeadamente: a estrutura analítica (EAP), a matriz de responsabilidade, a lista de atividades. Por aí já se vislumbra que se está manejando com missão de não limitada complexidade.

$\mathrm{Na}$ evolução a seguir, o próximo passo refere-se a situações envolvidas na 'montagem do cronograma'. Realmente, aqueles que estão acostumados a identificar este recurso apenas como representação gráfica de determinada sequência de eventos, certamente, se surpreenderão ao constatar a virtualidade e o dinamismo que se adensam nessa construção quando tecnicamente bem orientada. Compõese de inumeráveis metodologias que permitem a adequação do mesmo como instrumento indutor de qualidade na trajetória da tarefa posta, seja ela de maior ou menor dimensão. Vale dizer, as técnicas incluídas neste segmento não correspondem tão somente à melhor expressão do concreto pensado, como muitos podem ser levados a admitir quando se cogita o assunto; pelo contrário, referem-se a formas pelas quais ajustes e adequações na representação promovem aperfeiçoamento e melhoria do trabalho em campo, pela explicitação das atividades para previsão e acompanhamento. Neste sentido, nivelamento, paralelismo e compressão revelamse estratégias aplicáveis ao contexto, tomadas como diretriz operacional a merecer menção expressa e clara revisão pelos autores, assim como suas potencialidades e limitações. Alternativas mais avançadas e contemporâneas são igualmente factíveis, como as técnicas CPM, PERT (Program Evaluation and Review Technique) e Corrente Crítica (Critical Chain Project Management), rememorando-se suas bases estatísticas.

'Lidando com dinheiro' e riscos situa-se como o tema do capítulo subsequente. Nele parte-se de que o custo de cada fase é o das atividades a ela pertencentes, sendo o final a soma do custo de suas fases acrescido do chamado nível de esforço (Level of effort, LOE), i.e., o custo adicional que ocorre durante todo o tempo, como o salário do gestor ou os encargos da manutenção. Começa-se, assim, com a essência da estimativa de orçamento conhecida como bottom up, racional e prudente, oposta à top down, modelo em que um orçamento total pré-aprovado deve ser apropriado à cada parte da EAP. Da síntese entre ambas, resulta a opção recomendada, que é abordada por meio do exemplo que rastreia todas as situações contempladas no livro. Exemplo criativo, aliás! De então para frente, percorre-se o desafio do desempenho, com suas realidades contábil e financeira, imbrincadas em categorias como: análise de valor agregado e reservas de contingência.

Nesse contexto, percebe-se que algo que jamais pode ser olvidado é a 'consideração dos riscos': por isso, o estudo de tais ocorrências também é imperioso, i.e., além de avaliação e discussão de respectivas probabilidade, impacto e exposição, há que se ter, igualmente, como preveni-los, definindo-lhes respostas e estratégias para combatê-los. Para isso, é-se levado a recorrer a diferentes possibilidades, como: o 'método Delphi' (opinião de profissionais experientes, a partir de lista de perguntas orientadas e submetidas anonimamente), brainstorming, análise Swot (identificação de problemas por meio da individualização de potências e fragilidades) e entrevistas com especialistas.

Os stakeholders constituem um dos objetos focados com atenção. Considerados em seu conceito amplo, são atores conceituados como grupo ou individuo afetado pela iniciativa, o que inclui, diretamente, desde respectivos financiadores e executivos, pela via da sustentação e fomento, até o público em geral, em face da relação de benefício e consumo. Tem-se, portanto, sempre que conhecêlos, entendê-los e analisá-los. Constata-se, igualmente, que 'Comunicação' é outro aspecto com presença não para ser ignorada, no sentido de garantir-se que as respectivas informações sejam geradas, armazenadas e enviadas com adequação. De igual sorte, a 'Qualidade' dispõe de especificidades delineadas para adoção com vistas à obtenção do sucesso que se busca. 
Ocorre, então, lidar com 'pessoas'. De fato, tecnologia, patrimônio, informações e tudo o mais afeito pode ser adquirido - facilidade não disponível no que se refere à atuação de uma equipe boa e competente; para este caso, há que se cursar, segundo o apresentado, com as sucessivas fases de formação, conflito, normatização, desempenho e desintegração, esta de proximidade variável segundo a duração, se de caráter mais transitório ou mais permanente. Neste universo, destaque é conferido à motivação, revisitada pelos enfoques clássicos das teorias das necessidades de Maslow, $X$ e $Y$ de $M c G r e g o r$ e da satisfação de Hersberg. A abordagem adotada, como se vê, é funcionalista, fato que gera justificadas restrições por ignorar toda a complexa trama de determinação da realidade social em que os acontecimentos se dão, como se os grupos humanos se organizassem e se movessem no vazio do anódino não histórico e não ideológico.
E assim, esquematicamente, o processo se conclui, enquanto planejamento, planificação, plano do plano. A seguir, entra em cena sua acepção ampliada, envolvendo a execução e controle, dimensões que configuram o outro domínio de habilidades indispensáveis, o qual, embora complementar, implica a aquisição de saberes e fazeres distintos, qual seja, o da 'gestão'.

Em síntese, retomando de onde se partiu, ao recomendar o livro tanto em termos de leitura quanto de educação permanente, cabem os registros da falta sentida e da sugestão posta de produção de capítulo adicional que trate de concepções e práticas mais especificamente acadêmico-científicas, algumas até paradigmas da intelectualidade contemporânea (como projetos colaborativo e multicêntrico; plagiarismo; autoria compartilhada), na perspectiva de síntese agregadora para com leitores desse tipo de perfil, seja para discussão nos círculos dos já iniciados, seja para assimilação pelos que ainda estão por conhecê-las. 
